\title{
Trace Metal(oid) Accumulation in Edible Crops and Poplar Cuttings Grown on Dredged Sediment Enriched Soil
}

\author{
Mohamad Assad, Michel Chalot, Fabienne Tatin-Froux, Valérie Bert, and Julien Parelle*
}

\begin{abstract}
The development of a biomonitor in the context of multipleelement contamination in urban environments was tested by comparing element transfer in edible crops and poplar (Populus trichocarpa Torr. $\times$ Populus maximowiczii A. Henry cutlivar 'Skado'). A multielemental analysis was performed with various common edible crops (cucumber [Cucumis sativus L.], pepper [Capsicum annuum L.], cabbage [Brassica oleracea L.], and lettuce [Lactuca sativa L.]) and the Skado poplar cultivar grown on soils that received sediments dredged from water canals in the 1960s. Sediments were distributed unevenly on the soil, allowing us to sample two types of areas that were either weakly (Area 1) or highly (Area 2) contaminated, mainly by $\mathrm{Cd}, \mathrm{Pb}$, and $\mathrm{Zn}$. We registered an accumulation of $\mathrm{Cd}$ and $\mathrm{Zn}$ in the edible parts of crops, with higher values recorded for leafy vegetables than for fruit vegetables. We did not detect any accumulation of $\mathrm{Pb}$ in the plant species studied. We calculated the fresh mass that must be consumed daily to reach tolerable daily intake (TDI) recommendations for each element and found evidence that $\mathrm{Cd}$ could be ingested in sufficient amounts to reach the TDI in this context. Poplar and pepper leaves accumulated more $\mathrm{Cd}$ and $\mathrm{Zn}$ than the edible parts of the study crops grown on both substrates, which suggests that poplar and pepper may be suitable species for biomonitoring element transfer to vegetation in this context.
\end{abstract}

\section{Core Ideas}

- We estimated element transfer from a dredged sediment enriched soil to plants.

- The suitability of poplar and edible crops as biomonitors was tested.

- The 'Skado' poplar cultivar was confirmed to be a suitable biomonitor candidate

- The pepper plant is a promising novel candidate in the context of urban gardening.
U RBAN GARDENING has recently experienced rapid development; however, the type and the provenance of the soils vary and could be contaminated by a complex mixture of different toxic compounds, such as trace elements. In this context, the development of a biomonitor might be needed as a cost-effective method to indicate the potential transfer of trace metal(oid)s (TMs) to the vegetation. The biomonitor should indeed reflect the quantity of TMs in the edible parts of a large variety of crop vegetables, and this indirect quantification should have a sufficient accuracy to indicate whether the concentrations measured in the plant tissues would suggest a concentration above the safety limits defined by public agencies in the edible crops grown in the vicinity. The use of plants as biomonitors has been described for atmospheric pollution evaluation using moss (Ares et al., 2012) and trees (for a review, see Tarricone et al., 2015). The use of trees has also been suggested for the biomonitoring of TMs in soils. For instance, poplar (Populus L. spp.), known for its ability to phytoextract $\mathrm{Cd}$ and $\mathrm{Zn}$ into its leaves (Laureysens et al., 2005; Migeon et al., 2009; Phanthavongsa et al., 2017), has been used as a biomonitor in different contamination conditions (Madejón et al., 2004, 2013). However, TM accumulation in plants is highly dependent on the environmental bioavailability of metals to plants, hereafter called metal bioavailability. This can be defined as the flux of metals across a given root surface area of a target plant species for a determined period of time (ISO, 2006; Harmsen, 2007). Metal bioavailability is distinct from environmental availability and is currently estimated by using physicochemical methods (based on the utilization of extraction methods that employ extractants such as $\mathrm{CaCl}_{2}$ or $\mathrm{NaNO}_{3}$; Menzies et al., 2007). The determination of metal bioavailability is indeed crucial for assessing food chain contamination and phytotoxicity (i.e., toxicological bioavailability; Peijnenburg et al., 1997). Recently, a plant-based biotest has been developed for the estimation of the bioavailability of soil contaminants (Bravin et al., 2010), and it has been validated as the International Standard ISO 16198:2015. This biotest is

M. Assad and M. Chalot, Lab. Chrono-Environnement, UMR CNRS 6249, Univ. de Bourgogne Franche-Comté, Pôle Univ. du Pays de Montbéliard, 4 Place Tharradin, BP 71427, 25211 Montbéliard, France; M. Chalot, Univ. de Lorraine, Faculté des Sciences et Technologies, BP 70239, Vandoeuvre-les-Nancy, 54506 France; F. Tatin-Froux and J. Parelle, Lab. Chrono-Environnement, UMR CNRS 6249, Univ. de Bourgogne Franche-Comté, 16 Route de Gray, 25030 Besançon Cedex, France; V. Bert, INERIS, Clean and Sustainable Technologies and Processes Unit, DRC/RISK, Parc Technologique Alata, BP2, 60550, Verneuil-en-Halatte, France. Assigned to Associate Editor Angelia Seyfferth.

Abbreviations: ICP-AES, inductively coupled plasma atomic emission spectrometry; LQ, limit(s) of quantification; PCA, principal component analysis; TDI, tolerable daily intake; TM, trace metal(oid). 
applicable to the assessment of environmental bioavailability of trace elements to plants, and it suggests three plant species (cabbage [Brassica oleracea L.], tall fescue [Festuca arundinacea Schreb.], and tomato [Lycopersicon esculentum Mill.]) for use in the standardized biotest procedure. Poplar indeed proved to be a useful bioindicator to assess the pollution of the urban environment (Laureysens et al., 2005; Celik et al., 2010; Sluchyk et al., 2014; Assad et al., 2016). Given our previous results (Assad et al., 2017), we tested the 'Skado' poplar cultivar (Populus trichocarpa Torr. $\times$ Populus maximowiczii A. Henry) as a candidate model plant that would reflect the transfer of TMs from soil to different crop vegetables. However, this previous study was limited to the particular context of a titanium ore landfill that would not reflect the current TM mixtures found in urban environments (such as $\mathrm{As}, \mathrm{Cd}, \mathrm{Cu}, \mathrm{Pb}, \mathrm{Zn}$, etc.), which is why we decided to extend our studies to other substrates that contained these elements.

The "Voies Navigables de France" is in charge of dredging canals in France, which is vital to maintain navigable waters and adequate depths for ship navigation. The management approach for the dredged material has usually been to dispose of it in neighboring areas (Bert et al., 2009). Traditional solutions to the management of dredged sediments, such as dumping at sea or disposal in landfills, have become increasingly inadequate, and alternative solutions such as beneficial use in civil engineering and manufacturing have been proposed. However, contaminated dredged sediments are often not readily recoverable due to their high content of contaminants and their consequent hazardous properties, especially when considering the growth of edible plants. Sediments are indeed a compartment in which contaminants mostly accumulate (for a review, see Akcil et al., 2015). The organic compounds can often be degraded by soil microorganisms, whereas the TMs show high persistence, although this depends on soil properties that may induce environmental problems. Because one of the major ecological concerns around the experimental site is the production of woody biomass, a large-scale field trial using woody species (including poplar) has recently been implemented in the site to test the impact of woody cover on metal phytostabilization potential (Ciadamidaro et al., 2017; Phanthavongsa et al., 2017). Although dredged canal sediments are no longer useful for agricultural purposes, we chose this dredged sediment storage facility to design the present study because it offers unique opportunities: (i) the studied area contain contrasting levels of contamination, which could be used to test the effect of soil element content; (ii) the TM mixture that has accumulated in these sediments (mainly As, $\mathrm{Cd}, \mathrm{Cr}, \mathrm{Cu}$, $\mathrm{Ni}, \mathrm{Pb}$, and $\mathrm{Zn}$ ) is of particular interest for the urban gardening issues; and (iii) the data recorded on poplar in this study will be compared with the long-term field results.

Previous studies showed that the TMs contained in amendments might end up in plants, whereas the accumulation rate highly depends on the species and organs. For example, in grapevines (Vitis vinifera L.) grown in polluted urban or industrial contexts in Serbia, all plant tissues contain large amounts of $\mathrm{Cu}$ except for the fruit, which is the edible part (Alagić et al., 2014). Concerning dredged sediments, similar observations were made by Ebbs et al. (2006) on bean (Phaseolus vulgaris L.), broccoli (Brassica oleracea L. var. botrytis L.), carrot (Daucus carota L. var. sativus Hoffm.), pepper (Capsicum annuum L.), and tomato and by Canet et al. (2003) on tomatoes and lettuce (Lactuca sativa
L.) grown on lake dredgings, in which the sediments had positive effects on nutrients contents. The authors concluded that these dredged sediments could be used for the production of vegetables intended for human consumption.

In the present study, we estimated element transfer from a soil that has received dredged sediments to various edibles crops in controlled conditions. Two leafy vegetables (lettuce and cabbage), two fruit vegetables (pepper and cucumber [Cucumis sativus L.]), and the tested model tree Skado poplar cultivar were grown on two substrates (from different area) with different levels of contamination. We compared the plant element content with the tolerable daily intake (TDI) defined by public agencies (Baars et al., 2001; INERIS, 2005; WHO, 2005; EFSA, 2006, 2009) and with the soil element content, as estimated by the total recoverable and $\mathrm{CaCl}_{2}$-extractible fractions. We hypothesized that the poplar leaves would quantitatively reflect the global transfer observed in all of the species for all elements, and we tested the same hypothesis using the leaves of fruit vegetables because of their easier accessibility in a gardening context.

\section{Materials and Methods}

\section{Substrate Preparation and Physicochemical Analyses}

Soils were collected in 2013 from a deposit site of dredged sediments located at Fresnes-sur-Escaut (Hauts-de-France, France; $50^{\circ} 25^{\prime} 47^{\prime \prime} \mathrm{N}, 3^{\circ} 35^{\prime} 7^{\prime \prime} \mathrm{E}$ ), which has been fully described in Ciadamidaro et al. (2017). The soil in an anthroposol derived from the sediments has a silt loam texture (sand $=18.6 \%$, silt $=57.4 \%$, clay $=15.1 \%, \mathrm{CaCO}_{3}=3.5 \%$, organic matter $=5.4 \%$ $\mathrm{pH}_{\text {water }}=7.6$, total $\mathrm{N}$ content $=3.5 \mathrm{~g} \mathrm{~kg}^{-1}, \mathrm{C} / \mathrm{N}=9.2$, cation exchange capacity $=164 \mathrm{mmol}_{\mathrm{c}} \mathrm{kg}^{-1}, \mathrm{~B}=0.5 \mathrm{mg} \mathrm{kg}^{-1}$, total $\mathrm{P}$ content $=190 \mathrm{mg} \mathrm{kg}^{-1}, \mathrm{~K}_{2} \mathrm{O}=248 \mathrm{mg} \mathrm{kg}^{-1}, \mathrm{MgO}=124 \mathrm{mg}$ $\mathrm{kg}^{-1}, \mathrm{CaO}=7627 \mathrm{mg} \mathrm{kg}^{-1}, \mathrm{Na}_{2} \mathrm{O}=19 \mathrm{mg} \mathrm{kg}^{-1}$; Ciadamidaro et al., 2017). Regarding TM soil contamination, we performed detailed analyses in 2011 and 2013 of the whole area, and we were able to clearly distinguish two areas (Ciadamidaro et al., 2017; Phanthavongsa et al., 2017), which allowed us to collect a weakly (from Area F1, Plot 32) and a highly polluted area (from Area F2, Plot 5) for the present paper. Approximately $50 \mathrm{~kg}$ of each soil area was collected, thoroughly mixed, and diluted with sand $(1 / 1 \mathrm{v} / \mathrm{v})$ prior to use to limit compaction in pot experiments. The sand-weakly polluted area and sand-highly polluted area mixtures are referred to as Substrate 1 and Substrate 2 , respectively, throughout the text, tables, and figures. Fertilizer (11-11-18 N-P-K, Osmocote Exact, detailed composition: N $=11 \%, \mathrm{P}=4.8 \%, \mathrm{~K}=14.9 \%, \mathrm{Fe}=0.25 \% ; \mathrm{Mn}=0.03 \%, \mathrm{~B}=$ $0.01 \%, \mathrm{Cu}=0.05 \%, \mathrm{Mo}=0.01 \%$, and $\mathrm{Zn}=0.01 \%)$ was added to each pot $\left(1.5 \mathrm{~g} \mathrm{pot}^{-1}\right)$ at the beginning of the experiment to ensure nonlimiting plant nutrition in the different substrates. Soil subsamples were collected before adding fertilizers and dried for further physicochemical analysis, as described below.

\section{Growth and Sampling Conditions}

Seeds from two leafy food crops, lettuce (Lactuca sativa 'Batavia Kamikaze') and cabbage (Brassica oleracea 'Mozart F1'), and two fruit food crops, cucumber (Cucumis sativus 'Raider F1') and pepper (Capsicum annuum 'Alby F1'), were allowed to germinate for $2 \mathrm{wk}$ in a loam substrate and were planted after cleaning the roots to ensure root contact with the contaminated 
substrates. Thirty-centimeter Skado poplar cuttings were planted directly into the contaminated substrates. Twelve plants per species were planted. Each plant was planted in individual 0.5-L pots containing Substrate 1 or Substrate 2. The climatic conditions of the growth chamber were as follows: daylight for $16 \mathrm{~h}$ (250-300 $\mu \mathrm{mol} \mathrm{m}^{-2} \mathrm{~s}^{-1}$ ), daytime temperature of $22^{\circ} \mathrm{C}$, nighttime temperature of $18^{\circ} \mathrm{C}$, and daytime and nighttime humidity of $30 \%$. One-half of the plants were collected after $32 \mathrm{~d}$ of growth, and the other half were collected after $56 \mathrm{~d}$. All leaves of the five species and the fruits of cucumber and pepper were sampled. The fruit and leaf tissues were carefully washed in deionized water to remove potential substrate particles, placed in separate paper bags, and dried at $40^{\circ} \mathrm{C}$ before analysis.

\section{Elemental Analysis}

To determine the available fractions of elements from the two areas (Table 1), $5 \mathrm{~g}$ of $2-\mathrm{mm}$ sieved soil was dried at $60^{\circ} \mathrm{C}$ for $48 \mathrm{~h}$ and incubated with $50 \mathrm{~mL}$ of $10 \mathrm{mM} \mathrm{CaCl}_{2}$ under agitation $(40 \mathrm{rpm})$ for $2 \mathrm{~h}$ at room temperature. The mixture was first filtered with ash-free filters, passed through a $0.45-\mu \mathrm{m}$ mesh, and acidified at $2 \%(\mathrm{v} / \mathrm{v})$ with $\mathrm{HNO}_{3}$ prior to being analyzed by inductively coupled plasma atomic emission spectrometry (ICP-AES, radial ICAP 6500 model, Thermo Fisher Scientific). The recoveries for the studied elements were between 77 and $110 \%$.

The extraction of total recoverable TMs from plant tissues (using $1.75 \mathrm{~mL}$ of $\mathrm{HNO}_{3}$ and $0.5 \mathrm{~mL}$ of $\mathrm{H}_{2} \mathrm{O}_{2}$ ) or soils (using $2 \mathrm{~mL}$ of $\mathrm{HNO}_{3}$ and $5 \mathrm{~mL}$ of $\mathrm{HCl}$ ) was performed after milling the samples $(125 \mathrm{mg}$ ) and mineralizing them in closed tubes placed in a block digestion system (DigiPREP, SCP Sciences). Gradual heating was used to achieve a final temperature of $100^{\circ} \mathrm{C}$ (total run of $265 \mathrm{~min}$ ). Then, ultrapure water (Millipore Milli-Q Integral 3 system) was added to a final volume of $12.5 \mathrm{~mL}$. Finally, filtration to $1 \mu \mathrm{m}$ was performed. The element concentrations were determined using ICP-AES, and all samples were analyzed in triplicate with certified reference materials, including oriental 'Basma' tobacco (Nicotiana tabacum L.) leaves (INCT-OBTL-5, LGC Promochem), Cucumis sativus fruits (IPE-817, LGC Promochem), and loamy clay soil (CRM052, LGC Promochem). The limits of quantification (LQ) and percentage recoveries are given in Supplemental Table S1.

The fresh mass $(\mathrm{kg})$ to be eaten daily by an adult of $60 \mathrm{~kg}$ (FM) to reach the TDI for each TM was calculated as follow:

$\mathrm{FM}=(\mathrm{TDI} /[\mathrm{TM}]) /(1-\mathrm{Wc})$ where TDI is the tolerable daily intake of the considered TM for an adult of $60 \mathrm{~kg}$, [TM] is the concentration of the considered TM ( $\mathrm{mg} \mathrm{kg}^{-1}$ dry mass), and $\mathrm{Wc}_{\mathrm{c}}$ is the mean water content measured in the crops (cabbage $=84 \%$, lettuce $=93 \%$, pepper fruits $=95 \%$, cucumber fruits $=95 \%$ ).

\section{Statistical Analysis}

All statistical analyses were performed using $\mathrm{R}$ software version 3.2.0 ( $\mathrm{R}$ Development Core Team, 2015). All tests were considered significant if $p<0.05$. Differences in element contents among species, sampling dates, organs (leaves and fruits), and soil areas were analyzed by a two-way ANOVA followed by Tukey-Kramer mean comparison test. To respect the postulates of ANOVA, the element contents were log transformed. All categories containing at least one individual below the LQ were removed from the statistical analysis according to Helsel (2010), who considered that replacement methods induce statistical bias, particularly when the sample size is small $(n=6$ in this study). The removed data were denoted " $<\mathrm{LQ}$ " in Table 1 , and the median and the number of samples above the LQ were noted. When fruit production was too low $(n \leq 2)$, the category was removed from the statistical analysis, and the median and the number of samples were noted. For all of the categories included in the statistical analysis, we reported the median \pm range. For the principal component analysis (PCA), all data from the fruits and leaves were pooled into two data frames (one per soil area), and data below the LQ were considered to be null.

\section{Results and Discussion}

\section{Soil Characteristics}

Although the entire area received dredged sediment in the early 1960s, the two sampled areas were clearly distinct based on the degree of contamination (Table 1; Phanthavongsa et al., 2017). The total soil concentrations of the major contaminants $(\mathrm{Cd}, \mathrm{Cu}, \mathrm{Pb}$, and $\mathrm{Zn})$ were 12 -fold $(\mathrm{Zn})$, sevenfold $(\mathrm{Pb})$, or 1.4-fold $(\mathrm{Cu})$ higher in Area 2 than in Area 1, whereas $\mathrm{Cd}$ was not detected in Area 1. The elements As, Co, Cr, and Ni were in the same order of magnitude, slightly above the indicative world means (Table 1). None of these TMs (except As and $\mathrm{Zn}$ in Area 2) could be recovered in the $\mathrm{CaCl}_{2}$-extractible fraction. This method is well approved for the estimation of $\mathrm{Cd}$, Ni and, $\mathrm{Zn}$ extractible fraction available for plants; however, the other studied metal(oid)s could have been under estimated (reviewed in Kim et al., 2015). Whatever, the low mobility of these elements

Table 1. Median and range trace metal(oid) concentrations in Area 1 and Area 2 (total recoverable concentrations and $\mathrm{CaCl}_{2}-\mathrm{extractible}$ fractions) and indicative world averages (from Kabata-Pendias, 2011). The number of replicates is indicated in parentheses. Cases in which the data were below the limit of quantification are denoted by $<\mathrm{LQ}$.

\begin{tabular}{|c|c|c|c|c|c|c|c|c|c|}
\hline Area & Trait & As & $\mathrm{Cd}$ & Co & $\mathrm{Cr}$ & $\mathrm{Cu}$ & $\mathrm{Ni}$ & $\mathrm{Pb}$ & $Z n$ \\
\hline & & & & & $-m$ & $y^{-1}$ & & & \\
\hline \multirow[t]{2}{*}{ Area 1 (3) } & $\begin{array}{l}\text { Total recoverable } \\
\text { concentration }\end{array}$ & $\begin{array}{c}13.3 \\
(11-19)\end{array}$ & $<\mathrm{LQ}$ & $\begin{array}{c}12.7 \\
(11-15)\end{array}$ & $\begin{array}{c}56.7 \\
(50-68)\end{array}$ & $\begin{array}{c}28.5 \\
(28-29)\end{array}$ & $\begin{array}{c}24.3 \\
(21-29)\end{array}$ & $\begin{array}{c}49.5 \\
(47-52)\end{array}$ & $\begin{array}{c}154.5 \\
(137-172)\end{array}$ \\
\hline & $\begin{array}{l}\mathrm{CaCl}_{2} \text {-extractible } \\
\text { fraction }\end{array}$ & $\begin{array}{c}0.02 \\
(0.01-0.03)\end{array}$ & $<\mathrm{LQ}$ & $<\mathrm{LQ}$ & $<\mathrm{LQ}$ & $<\mathrm{LQ}$ & $<\mathrm{LQ}$ & $<\mathrm{LQ}$ & $<\mathrm{LQ}$ \\
\hline \multirow[t]{2}{*}{ Area 2 (2) } & $\begin{array}{l}\text { Total recoverable } \\
\text { concentration }\end{array}$ & $\begin{array}{c}24 \\
(23-25)\end{array}$ & $\begin{array}{c}7.5 \\
(7-8)\end{array}$ & $\begin{array}{c}17.5 \\
(16-19)\end{array}$ & $\begin{array}{c}79.5 \\
(72-87)\end{array}$ & $\begin{array}{c}95.5 \\
(87-104)\end{array}$ & $\begin{array}{c}37 \\
(37-37)\end{array}$ & $\begin{array}{c}366.5 \\
(328-405)\end{array}$ & $\begin{array}{c}1895.5 \\
(1720-2071)\end{array}$ \\
\hline & $\begin{array}{l}\mathrm{CaCl}_{2} \text {-extractible } \\
\text { fraction }\end{array}$ & $\begin{array}{c}0.01 \\
(0.01-0.01)\end{array}$ & $<\mathrm{LQ}$ & $<\mathrm{LQ}$ & $<\mathrm{LQ}$ & $<\mathrm{LQ}$ & $<\mathrm{LQ}$ & $<\mathrm{LQ}$ & $\begin{array}{c}0.1 \\
(0.1-0.1)\end{array}$ \\
\hline \multicolumn{2}{|c|}{$\begin{array}{l}\text { Indicative world average } \\
\text { (Kabata-Pendias, 2011) }\end{array}$} & 6.8 & 0.41 & 11.3 & 60 & 38.9 & 29 & 27 & 70 \\
\hline
\end{tabular}

Journal of Environmental Quality 
should be due principally to the chemical characteristic of the studded soils; indeed the high level of organic matter (5.4\%) and the high $\mathrm{pH}$ (7.6) are well known to highly reduce the mobility of metal(oid)s.

\section{Transfer of Trace Metal(oid) to the Plants}

The PCA revealed the similarities among the plants species (and between organs) in their capacities to accumulate TMs, regardless of the substrate (Fig. 1). The various tested plant species and organs could be grouped into three categories: those accumulating mainly $\mathrm{Cd}, \mathrm{Zn}$, and $\mathrm{Ni}$, mainly the poplar and pepper leaves; those accumulating As, Co, and $\mathrm{Ni}$ (and $\mathrm{Cr}$ on Substrate 1), mainly the fruits of cucumber; and finally, those accumulating TMs to a much lower extent, mainly the leaves of cabbage and lettuce and the fruits of pepper. None of the plant species tested in this experiment was able to accumulate all of the studied TMs.
A more detailed analysis of TMs in the tested plants revealed three groups of elements (Table 2). For the first group (As, Co, $\mathrm{Cr}$, and $\mathrm{Pb}$ ), we did not observe transfer from the soil to the plant tissues in either of the two substrates, which was consistent with the low or undetectable $\mathrm{CaCl}_{2}$-extractible fractions measured for these elements (Table 1). A noticeable exception was the presence of $\mathrm{As}, \mathrm{Co}, \mathrm{Cr}$, and $\mathrm{Pb}$ in a few cucumber and pepper fruits. Arsenic has been reported to accumulate in the edible parts of different plant species ( $\mathrm{Li}$ et al., 2016). McBride et al. (2015) also found a significant accumulation of As in carrot, lettuce, green bean (Phaseolus vulgaris L.), and tomato; however, the tested concentrations were much higher than those measured in our studied substrates. Rosas-Castor et al. (2014) observed As accumulation in maize (Zea mays L.) when grown on a soil with an As concentration comparable with that in our substrates, but their recorded values in the shoot were mainly below our LQ for As (1.24 $\mathrm{mg} \mathrm{kg}^{-1}$, Supplemental Table S1). The elevated total and

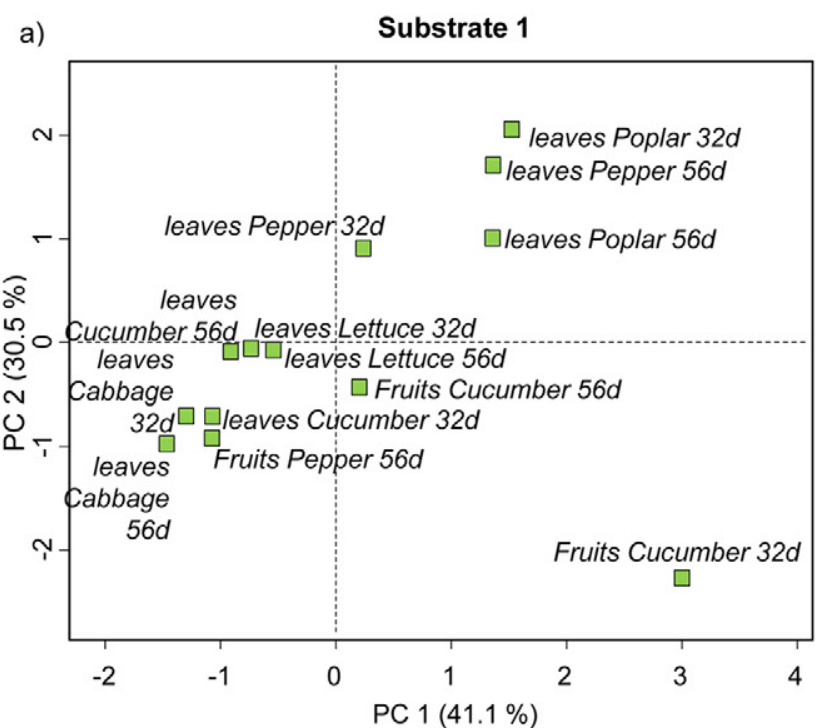

c)

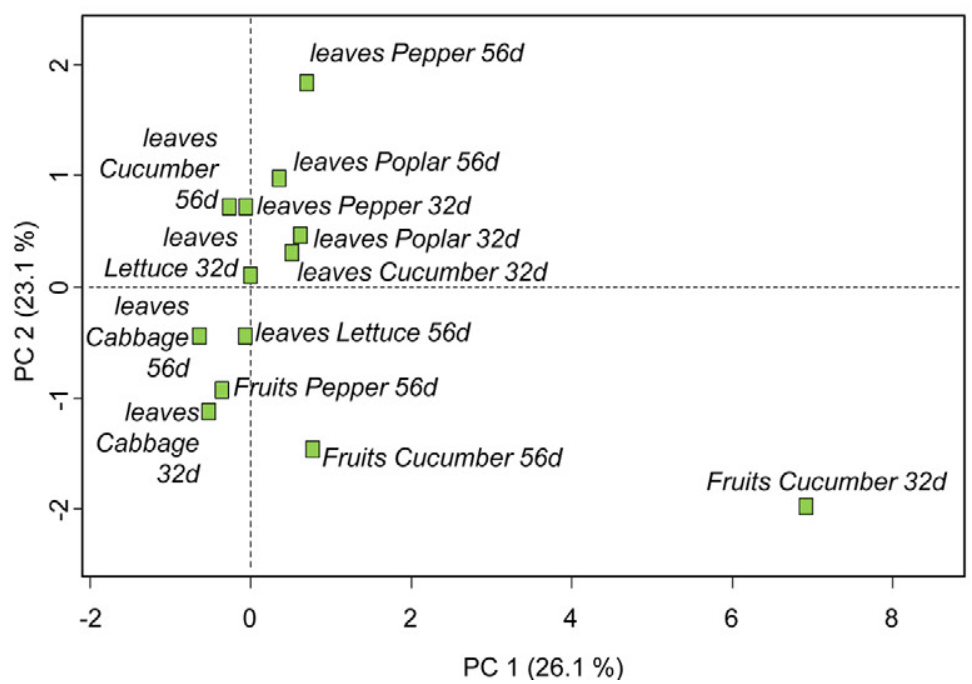

b)

\section{Substrate 1}

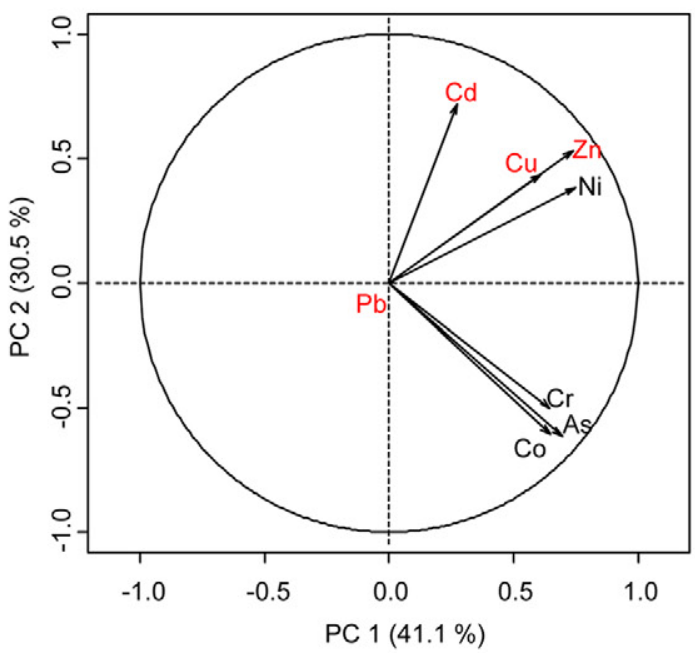

d)

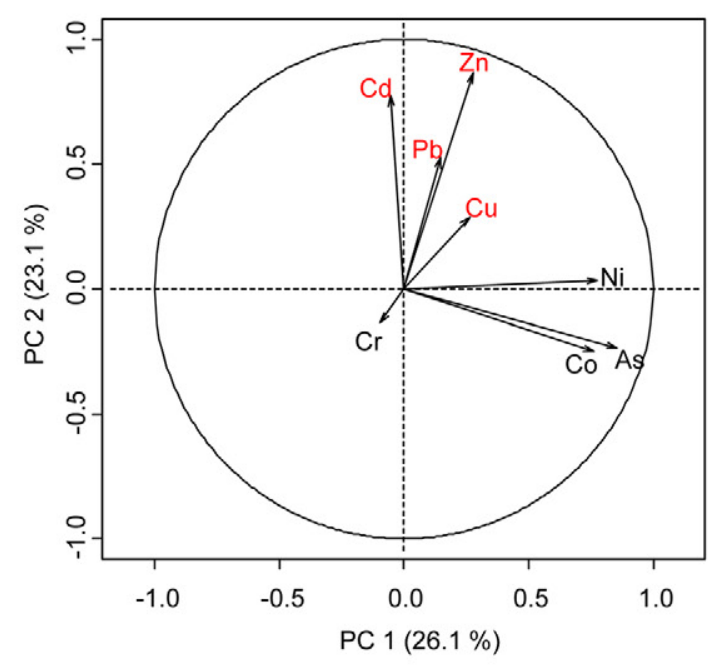

Fig. 1. Principal component analysis of trace metal(oid) content in plant tissues. Data are shown separately for (a, b) Substrate 1 and (c, d) Substrate 2. The percentage of explained variance by the components is indicated in parenthesis. Panels a and c show projections of the barycenter of each plant species (green squares) on the two main components (PC 1 and PC 2) for leaves and fruits after $32 \mathrm{~d}$ or $52 \mathrm{~d}$ of growth. Panels b and d show projections of each element vector on the two main components (black arrows); the elements specific to the environmental context are highlighted in red. 


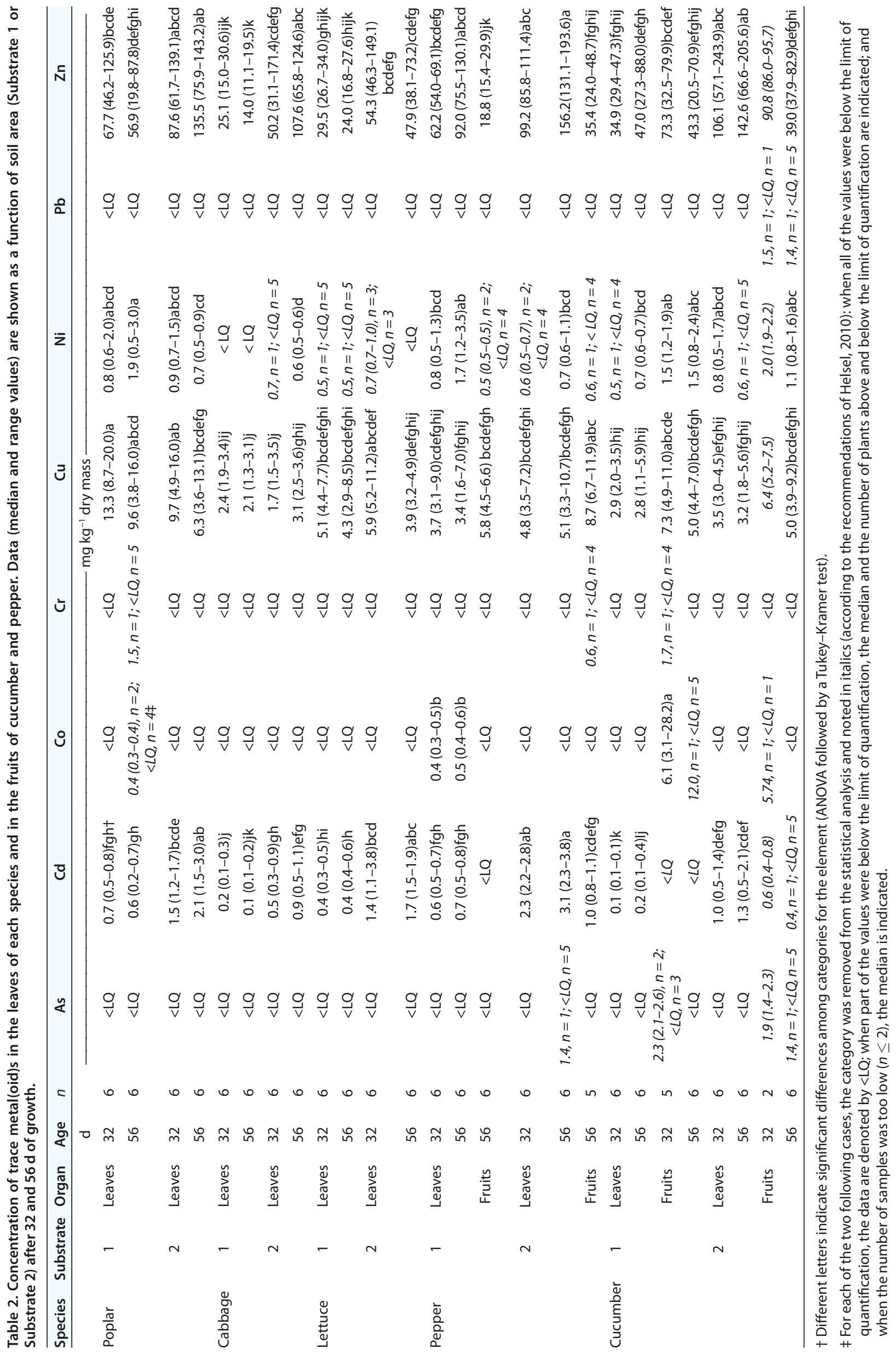


$\mathrm{CaCl}_{2}$-extractible fractions of As were therefore not reflected by As content in plants. The lack of detectable $\mathrm{Pb}$ in most of the plants from our study confirmed the low $\mathrm{CaCl}_{2}$-extractible fraction of $\mathrm{Pb}$ in substrates from both areas. Yadav et al. (2015) found that $\mathrm{Pb}$ could be detected in many edible crops (wheat [Triticum aestivum L.], fenugreek [Trigonella foenum-graecum L.], radish [Raphanus sativus L.], spinach [Spinacia oleracea L.], bean, clover [Trifolium L. spp.], and sorghum [Sorghum bicolor (L.) Moench]); however, their plants were irrigated with contaminated sewage industrial effluents, which could have induced much higher bioavailability (because the authors measured the DTPA [diethylenetriamine pentaacetate]-extractable fraction, a direct comparison with our results is not feasible). Cobalt was only detected in cucumber fruits (on the two substrates) and in pepper leaves, although at much lower levels (on Substrate 1). Since Co may also have been added to the substrate by the fertilizer that was used in our study, we cannot confirm the transfer of Co from the dredged sediment.

The second group of TMs is represented by $\mathrm{Cu}$ and $\mathrm{Ni}$, which were detected in the fruits and leaves of most of the edible crops and in the leaves of poplar (Table 2). Despite higher total $\mathrm{Cu}$ or slightly higher total Ni content in Substrate 2 compared with Substrate 1 (Table 1), we did not find significant differences in their accumulation in plant tissues between the two soils. As mentioned for $\mathrm{Co}, \mathrm{Cu}$ might also originate from the fertilizer. The values obtained for $\mathrm{Cu}$ in the present study are similar to those given in the Ciqual tables (French food composition tables) for the edible parts of the crops (ANSES, 2013). The highest $\mathrm{Ni}$ content was found for poplar leaves and cucumber fruits (Table 2). For all other species, the measured Ni concentrations were mostly $<1 \mathrm{mg} \mathrm{kg}^{-1}$ or below the LQ $\left(<0.47 \mathrm{mg} \mathrm{kg}^{-1}\right)$.

Cadmium and $\mathrm{Zn}$ belong to the third group of TMs. They accumulated at significantly higher levels in most plant tissues grown on Substrate 2 compared with Substrate 1 (Table 2), which reflects the differences in TM soil concentrations. Cadmium and $\mathrm{Zn}$ are indeed well known to be highly correlated, mainly due to membrane-unspecific transporters of the two elements (Gupta et al., 2016). Cucumber and pepper leaves accumulated higher $\mathrm{Cd}$ and $\mathrm{Zn}$ levels than fruits, as previously observed in tomato, cherry (Prunus avium L.), grape, and strawberry [Fragaria $\times$ ananassa (Weston) Duchesne ex Rozie] by Bagdatlioglu et al. (2010) and in apricot (Prunus armeniaca L.) and fig (Ficus carica L.) by Oteef et al. (2015). As a consequence, the accumulation of TMs in cucumber and pepper fruits could have been lowered by the storage of excess TMs in leaf tissues in these species.

\section{Tolerable Daily Intake of Elements}

Public agencies recommend TDI values for each element, reflecting the maximum amount above which no effect for human health has been recorded. Using these values, we calculated the fresh mass that would need to be taken in daily to reach this TDI for each edible crop and for each element in our experimental context (Table 3). Such calculations do not consider a complete exposure scenario of the human population, such as the target hazard quotients used by Harmanescu et al. (2011), but they do allow one to determine whether the recorded element content could be taken in in sufficient amounts to have an effect on human health. According to our calculation method, we found that several kilograms of the studied crops must be eaten daily to reach the TDI of $\mathrm{Cu}$ and $\mathrm{Ni}$ in this context. For Co, we observed that only 100 to $200 \mathrm{~g}$ of fresh mass of cucumber fruit would need to be consumed to reach the TDI; however, as mentioned above, the presence of Co in the fertilizer does not allow us to conclude that the Co content in crops originated only from the TMs present in the dredged sediments. For $\mathrm{Cr}$ and $\mathrm{Ni}$, a number of values were below the LQ, but we observed that for the highest values recorded, several kilograms of fresh crops must be consumed daily to reach the TDI of these two elements. However, this observation could not apply to As nor $\mathrm{Pb}$ because of their elevated LQ compared with other elements (1.24 and $1.18 \mathrm{mg} \mathrm{kg}^{-1}$, respectively, Supplemental Table S1).

For Cd, only several hundred grams of fresh mass of each of the edible crops tested in the present study must be eaten daily to exceed the recommended TDI. Although a similar accumulation pattern was recorded for $\mathrm{Zn}$ in the different crop species, we observed that several kilograms of fresh mass must be eaten daily to reach the TDI of this element for all of the tested crops. For both elements, higher concentrations were recorded in leafy vegetables (lettuce and cabbage) than in fruit vegetables (cucumber and pepper). As a consequence, the intake of a half portion of fruit vegetables, compared with leafy vegetables, is needed to take in $\mathrm{Zn}$ and $\mathrm{Cd}$ at a similar order of magnitude.

Despite the low transfer of TMs from the soil to the plant tissues, these data prompted us to conclude that the consumption of vegetable crops grown on such soils (receiving dredged sediments highly enriched in $\mathrm{Cd}$ and $\mathrm{Zn}$ ) represents a potential risk for consumers through $\mathrm{Cd}$ exposure. Although these sediments clearly must not be used for gardening, we could conclude that selecting the cultivation of fruit vegetable crops instead of leafy vegetables would be more appropriate for urban gardening with the potential for exposure to similar TMs.

\section{Accumulation of Trace Metal(oid)s in Poplar and in Leaves of Cucumber and Pepper}

We tested the leaves of the model plant poplar as a potential biomonitor for TM transfer from soil to crops. Additionally, we tested the leaves of pepper and cucumber for the same purpose, which are more directly accessible in a gardening context. The leaves of the three species showed similar patterns of accumulation of TMs than those measured in the edible parts of vegetable crops. These leaves accumulated $\mathrm{Cd}$ and $\mathrm{Zn}$ and showed no significant accumulation of $\mathrm{As}, \mathrm{Cr}, \mathrm{Cu}$, and $\mathrm{Pb}$ (Table 2). We observed an accumulation of $\mathrm{Ni}$ in poplar leaves in Substrate 1 and of Co in the pepper leaves on Substrate 1. Across all organs of all the vegetables tested, the highest values of the accumulated TMs (resumed by the PCA, Fig. 1) were recorded for the leaves of pepper and poplar on both substrates.

Therefore, the leaves of pepper and of poplar had the capacity to maximize TM content, which could be transferred to the vegetation in this experimental context. Additionally, we noticed that the nonedible parts (i.e., leaves) of these fruit crops should not be used for feedstuff. The maximum $\mathrm{Cd}$ level allowed in animal feed is $0.88 \mu \mathrm{g} \mathrm{g}^{-1}$ dry mass (EU, 2002), and this threshold value is clearly reached in our experimental design (Table 2), which would induce the transfer of $\mathrm{Cd}$ and its accumulation in the higher trophic levels of the food chain and in turn cause indirect impacts on human health. 
Table 3. Fresh mass $(\mathrm{kg})$ to be eaten daily by an adult of $60 \mathrm{~kg}$ to reach the tolerable daily intake (TDI) for each trace metal(oid). The value and source of the used TDI for calculation are shown at the bottom of the tables (see the Materials and methods section for details on calculation). Water contents used for calculation were recorded in leaves and fruits samples (cabbage leaves $=84 \%$, lettuce leaves $=93 \%$, pepper fruits $=95 \%$, cucumber fruits $=95 \%)$. Data are shown after $56 \mathrm{~d}$ of growth.

\begin{tabular}{|c|c|c|c|c|c|c|c|c|c|c|c|}
\hline Species & Substrate & Organ & Age & As & $\mathrm{Cd}$ & Co & Crt & $\mathrm{Cu}$ & $\mathrm{Ni}$ & $\mathrm{Pb}$ & $\mathrm{Zn}$ \\
\hline & & & d & 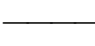 & & & $\mathrm{kg}$ & 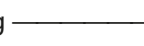 & 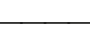 & 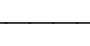 & 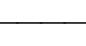 \\
\hline \multirow[t]{4}{*}{ Cabbage } & 1 & Leaves & 32 & n.m. $\neq$ & 1.9 & n.m. & n.m. & 21.0 & n.m. & n.m. & 6.8 \\
\hline & & & 56 & n.m. & 2.9 & n.m. & n.m. & 24.3 & n.m. & n.m. & 10.8 \\
\hline & 2 & Leaves & 32 & n.m. & 0.6 & n.m. & n.m. & 25.7 & 6.1 & n.m. & 2.3 \\
\hline & & & 56 & n.m. & 0.4 & n.m. & n.m. & 17.3 & 8.1 & n.m. & 1.5 \\
\hline \multirow[t]{4}{*}{ Lettuce } & 1 & Leaves & 32 & n.m. & 2.1 & n.m. & n.m. & 22.5 & 17.9 & n.m. & 11.9 \\
\hline & & & 56 & n.m. & 1.9 & n.m. & n.m. & 24.2 & 20.1 & n.m. & 15.6 \\
\hline & 2 & Leaves & 32 & n.m. & 0.5 & n.m. & n.m. & 16.7 & 13.1 & n.m. & 5.2 \\
\hline & & & 56 & n.m. & 0.5 & n.m. & n.m. & 30.7 & n.m. & n.m. & 6.9 \\
\hline \multirow[t]{2}{*}{ Pepper } & 1 & Fruits & 56 & n.m. & n.m. & n.m. & n.m. & 29.5 & 27.4 & n.m. & 24.9 \\
\hline & 2 & Fruits & 56 & n.m. & 1.3 & n.m. & 6.7 & 18.8 & 24.5 & n.m. & 14.3 \\
\hline \multirow[t]{4}{*}{ Cucumber } & 1 & Fruits & 32 & n.m. & n.m. & 0.2 & 2.4 & 21.9 & 9.5 & n.m. & 7.4 \\
\hline & & & 56 & n.m. & n.m. & 0.1 & n.m. & 31.3 & 9.3 & n.m. & 11.8 \\
\hline & 2 & Fruits & 32 & n.m. & 2.0 & 0.05 & n.m. & 26.4 & 7.0 & n.m. & 5.5 \\
\hline & & & 56 & n.m. & 2.7 & n.m. & n.m. & 30.8 & 12.3 & n.m. & 10.7 \\
\hline \multicolumn{4}{|c|}{ TDI (mg d ${ }^{-1} 60 \mathrm{~kg}^{-1}$ corporal mass) } & 0.21 & 0.06 & 0.084 & $0.21[$ for $\mathrm{Cr}(\mathrm{Vl})]$ & 8.4 & 0.72 & 0.042 & 25 \\
\hline \multicolumn{4}{|l|}{ Source } & $\begin{array}{c}\text { EFSA } \\
(2009)\end{array}$ & $\begin{array}{c}\text { EFSA } \\
(2009)\end{array}$ & $\begin{array}{l}\text { Baars et al. } \\
\quad(2001)\end{array}$ & $\begin{array}{l}\text { INERIS } \\
(2005)\end{array}$ & $\begin{array}{l}\text { Baars et al. } \\
\quad(2001)\end{array}$ & $\begin{array}{l}\text { WHO } \\
(2005)\end{array}$ & $\begin{array}{c}\text { EFSA } \\
(2009)\end{array}$ & $\begin{array}{c}\text { EFSA } \\
(2009)\end{array}$ \\
\hline
\end{tabular}

† For $\mathrm{Cr}$, the calculation was performed only for the most toxic form $\mathrm{Cr}(\mathrm{VI})$ to minimize the fresh mass intake to reach the $\mathrm{TDI}$.

¥ When values were below the limit of quantification, no calculation was performed and data are denoted as n.m. (not measured).

\section{Biomonitoring Potential of the Tested Species}

Assessing the risk for human health of TM intake due to crop consumption by simply measuring the concentrations of total soil TMs is now considered irrelevant (Harmanescu et al., 2011). This measurement indeed does not allow one to predict the transfer of any element to vegetation, it does not provide information about limit values for human health toxicity, and it does not take into account the interspecific variations of TM uptake. The use of sentinel vegetation has been widely considered but mostly for atmospheric pollution for which direct prediction is difficult (Smodiš et al., 2004). To reflect risk, an efficient plant biomonitor should quantitatively reflect the level of element transfer from soil to the edible parts (Smodiš et al., 2004), take into account that the level of transfer varies among plant species, and be relevant for all of the potentially toxic elements in the specific context. Matching the interspecific diversity and the quantitative assessment of the risk of transfer suggests, as a first approach, the use of a large panel of sentinel plants. However, the analytical and human costs associated with such a concept would be economically irrelevant. Reducing the approach to a single plant biomonitor would be more relevant if the plant biomonitor reflects the transfer for all of the elements for which a transfer is suspected in a specific context. In the context of gardening, the objective is generally to conclude an absence of risk; for this purpose, the chosen biomonitor should assess the maximum element transfer to vegetation.

Poplar is a particularly interesting candidate because of its wellknown and high capacity to accumulate various TMs (Laureysens et al., 2005; Migeon et al., 2009; Celik et al., 2010; Sluchyk et al., 2014). The Skado poplar cultivar is of particular interest, as demonstrated in our previous papers, because it may accumulate $\mathrm{Cr}, \mathrm{Ni}, \mathrm{Mn}$ (Assad et al., 2017), and Hg (Assad et al., 2016), in addition to $\mathrm{Cd}$ and $\mathrm{Zn}$. Indeed, in the present study, the Skado poplar cultivar accumulated a significantly higher content of $\mathrm{Cd}$ in its leaves when grown on Substrate 2 compared with Substrate 1. Compared with edible crops, poplar leaves encompass the transfer of most TMs present at our experimental site to the vegetation. We also found that pepper is a particularly promising model. Indeed, the use of pepper as a passive biomonitor planted directly into gardens should be a relevant development of the present study, since pepper leaves mostly accumulate the TMs $\mathrm{Cd}$ and $\mathrm{Zn}$ and have the capacity to accumulate $\mathrm{Mn}, \mathrm{Fe}, \mathrm{Ni}$ (Assad et al., 2017), and $\mathrm{Hg}$ (Assad et al., unpublished data, 2016).

\section{Supplemental Material}

The supplemental material includes the LQs for elements and recovery percentages for the certified material.

\section{Acknowledgments}

This work was supported by the French National Research Agency (ANR BIOFILTREE 2010-INTB-1703-01), the Région FrancheComté (Environnement-Homme-Territoire 2014-069), and the Pays de Montbéliard Agglomération (13/070-203-2015). M. Assad's Ph.D. grant was supported by the Ministry of Higher Education of the Syrian Arab Republic. We acknowledge Dr. Nadia Morin-Crini and Caroline Amiot for the ICP-AES analysis and K. Perronnet for useful advice on the manuscript. We thank the VNF (Voies Navigables de France) for providing us with access to the experimental site. The authors declare no conflicts of interest.

\section{References}

Akcil, A., C. Erust, S. Ozdemiroglu, V. Fonti, and F. Beolchini. 2015. A review of approaches and techniques used in aquatic contaminated sediments: Metal removal and stabilization by chemical and biotechnological processes. J. Clean. Prod. 86:24-36. doi:10.1016/j.jclepro.2014.08.009

Alagić, S.Č., S.B. Tošić, M.D. Dimitrijević, M.M. Antonijević, and M.M. Nujkić. 2014. Assessment of the quality of polluted areas based on the content of heavy metals in different organs of the grapevine (Vitis vinifera) cv Tamjanika. Environ. Sci. Pollut. Res. 22:7155-7175. doi:10.1007/ s11356-014-3933-1 
ANSES. 2013. Tables Ciqual: French food composite table. Agence natl. sécur. sanit. https://pro.anses.fr/TableCIQUAL/ (accessed May 2016).

Ares, A., J.R. Aboal, A. Carballeira, S. Giordano, P. Adamo, and J.A. Fernandez. 2012. Moss bag biomonitoring: A methodological review. Sci. Total Environ. 432:143-158. doi:10.1016/j.scitotenv.2012.05.087 [erratum: 475:153-154].

Assad, M., J. Parelle, D. Cazaux, F. Gimbert, M. Chalot, and F. Tatin-Froux. 2016. Mercury uptake into poplar leaves. Chemosphere 146:1-7. doi:10.1016/j. chemosphere.2015.11.103

Assad, M., F. Tatin-Froux, D. Blaudez, M. Chalot, and J. Parelle. 2017. Accumulation of trace elements in edible crops and poplar grown on a titanium ore landfill. Environ. Sci. Pollut. Res. 24:5019-5031. doi:10.1007/ s11356-016-8242-4

Baars, A., R.M.C. Theelen, P.J.C.M. Janssen, J.M. Hesse, M.E. van Apeldoorn, M.C.M. Meijerink, et al. 2001. Re-evaluation of human-toxicological maximum permissible risk levels. RIVM Rep. 711701025. Rijksinst. Volksgezond. Milieu, Bilthoven, the Netherlands.

Bagdatlioglu, N., C. Nergiz, and P.G. Ergonul. 2010. Heavy metal levels in leafy vegetables and some selected fruits. J. Verbraucherschutz Leb. 5:421-428. doi:10.1007/s00003-010-0594-y

Bert, V., P. Seuntjens, W. Dejonghe, S. Lacherez, H. Thuy, and B. Vandecasteele. 2009. Phytoremediation as a management option for contaminated sediments in tidal marshes, flood control areas and dredged sediment landfill sites. Environ. Sci. Pollut. Res. 16:745-64. doi:10.1007/s11356-009-0205-6

Bravin, M.N., A.M. Michaud, B. Larabi, and P. Hinsinger. 2010. RHIZOtest: A plant-based biotest to account for rhizosphere processes when assessing copper bioavailability. Environ. Pollut. 158:3330-3337. doi:10.1016/j. envpol.2010.07.029

Canet, R., C. Chaves, F. Pomares, and R. Albiach. 2003. Agricultural use of sediments from the Albufera Lake (eastern Spain). Agric. Ecosyst. Environ. 95:29-36. doi:10.1016/S0167-8809(02)00171-8

Celik, S., E. Yucei, S. Celik, S. Gucel, and M. Ozturk. 2010. Carolina poplar (Populus $\times$ canadensis Moench) as a biomonitor of trace elements in Black Sea region of Turkey. J. Environ. Biol. 31:225-232.

Ciadamidaro, L., O. Girardclos, V. Bert, C. Zappelini, L. Yung, J. Foulon, et al. 2017. Poplar biomass production at phytomanagement sites is significantly enhanced by mycorrhizal inoculation. Environ. Exp. Bot. 139:48-56. doi:10.1016/j.envexpbot.2017.04.004

Ebbs, S., J. Talbott, and R. Sankaran. 2006. Cultivation of garden vegetables in Peoria Pool sediments from the Illinois River: A case study in trace element accumulation and dietary exposures. Environ. Int. 32:766-774. doi:10.1016/j.envint.2006.03.013

EFSA. 2006. Tolerable upper intake levels for vitamins and minerals. Eur. Food Saf. Auth., Parma, Italy.

EFSA. 2009. Cadmium in food: Scientific opinion of the Panel on Contaminants in the Food Chain. The EFSA Journal 980:1-139.

EU. 2002. Directive 2002/32/EC of the European Parliament and of the Council of 7 May 2002 on undesirable substances in animal feed. Eur. Union, Brussels.

Gupta, N., H. Ram, and B. Kumar. 2016. Mechanism of zinc absorption in plants: Uptake, transport, translocation and accumulation. Rev. Environ. Sci. Biotechnol. 15:89-109. doi:10.1007/s11157-016-9390-1

Harmanescu, M., L.M. Alda, D.M. Bordean, I. Gogoasa, and I. Gergen. 2011. Heavy metals health risk assessment for population via consumption of vegetables grown in old mining area; a case study: Banat County, Romania. Chem. Cent. J. 5:64. doi:10.1186/1752-153X-5-64

Harmsen, J. 2007. Measuring bioavailability: From a scientific approach to standard methods. J. Environ. Qual. 36:1420-1428. doi:10.2134/ jeq2006.0492

Helsel, D. 2010. Much ado about next to nothing: Incorporating nondetects in science. Ann. Occup. Hyg. 54:257-262.

INERIS. 2005. Fiche de données toxicologiques et environnementales des substances chimiques: Chrome et ses dérivés. Inst. natl. l'environ. ind. risques. www. ineris.fr/substances/fr/substance/getDocument/2739 (accessed May 2016).

ISO. 2006. Soil quality and guidance for the selection and application of methods for the assessment of bioavailability in soil and soil materials. ISO/DIS 17402. Int. Org. Stand., Geneva, Switzerland.

Kabata-Pendias, A. 2011. Trace elements in soils and plants. 4th ed. CRC Press, Boca Raton, FL.
Kim, R.-Y., J.-K. Yoon, T.-S. Kim, J.E. Yang, G. Owens, and K.-R. Kim. 2015. Bioavailability of heavy metals in soils: Definitions and practical implementation: A critical review. Environ. Geochem. Health 37:1041-1061. doi:10.1007/s10653-015-9695-y

Laureysens, I., L. De Temmerman, T. Hastir, M. Van Gysel, and R. Ceulemans. 2005. Clonal variation in heavy metal accumulation and biomass production in a poplar coppice culture. II. Vertical distribution and phytoextraction potential. Environ. Pollut. 133:541-551. doi:10.1016/j. envpol.2004.06.013

Li, N., J. Wang, and W.-Y. Song. 2016. Arsenic uptake and translocation in plants. Plant Cell Physiol. 57:4-13. doi:10.1093/pcp/pcv143

Madejón, P., L. Ciadamidaro, T. Marañón, and J.M. Murillo. 2013. Long-term biomonitoring of soil contamination using poplar trees: Accumulation of trace elements in leaves and fruits. Int. J. Phytorem. 15:602-614. doi:10.1 080/15226514.2012.723062

Madejón, P., T. Marañón, J.M. Murillo, and B. Robinson. 2004. White poplar (Populus alba) as a biomonitor of trace elements in contaminated riparian forests. Environ. Pollut. 132:145-155. doi:10.1016/j.envpol.2004.03.015

McBride, M.B., H.A. Shayler, J.M. Russell-Anelli, H.M. Spliethoff, and L.G. Marquez-Bravo. 2015. Arsenic and lead uptake by vegetable crops grown on an old orchard site amended with compost. Water Air Soil Pollut. 226:265. doi:10.1007/s11270-015-2529-9

Menzies, N.W., M.J. Donn, and P.M. Kopittke. 2007. Evaluation of extractants for estimation of the phytoavailable trace metals in soils. Environ. Pollut. 145:121-130. doi:10.1016/j.envpol.2006.03.021

Migeon, A., P. Richaud, F. Guinet, M. Chalot, and D. Blaudez. 2009. Metal accumulation by woody species on contaminated sites in the north of France. Water Air Soil Pollut. 204:89. doi:10.1007/s11270-009-0029-5

Oteef, M.D.Y., K.F. Fawy, H.S.M. Abd-Rabboh, and A.M. Idris. 2015. Levels of zinc, copper, cadmium, and lead in fruits and vegetables grown and consumed in Aseer region, Saudi Arabia. Environ. Monit. Assess. 187:676. doi:10.1007/s10661-015-4905-8

Peijnenburg, W.J.G.M., L. Posthuma, H.J.P. Eijsackers, and H.E. Allen. 1997. A conceptual framework for implementation of bioavailability of metals for environmental management purposes. Ecotoxicol. Environ. Saf. 37:163172. doi:10.1006/eesa.1997.1539

Phanthavongsa, P., M. Chalot, A. Papin, L. Lacercat-Didier, S. Roy, D. Blaudez, and V. Bert. 2017. Effect of mycorrhizal inoculation on metal accumulation by poplar leaves at phytomanaged sites. Environ. Exp. Bot. 143:7281. doi:10.1016/j.envexpbot.2017.08.012

R Development Core Team. 2015. R: A language and environment for statistical computing. R Found. Stat. Comput., Vienna, Austria. http://www.Rproject.org/ (accessed April 2015).

Rosas-Castor, J.M., J.L. Guzmán-Mar, J.M. Alfaro-Barbosa, A. HernándezRamírez, I.N. Pérez-Maldonado, A. Caballero-Quintero, and L. HinojosaReyes. 2014. Evaluation of the transfer of soil arsenic to maize crops in suburban areas of San Luis Potosi, Mexico. Sci. Total Environ. 497-498:153162. doi: $10.1016 / j$.scitotenv.2014.07.072

Sluchyk, V., I. Sluchyk, and A. Shyichuk. 2014. Assessment of both environmental cytotoxicity and trace metal pollution using Populus simonii Carr. as a bioindicator. Environ. Monit. Assess. 186:6645-6650. doi:10.1007/ s10661-014-3879-2

Smodiš, B., M.L. Pignata, M. Saiki, E. Cortés, N. Bangfa, B. Markert, et al. 2004. Validation and application of plants as biomonitors of trace element atmospheric pollution: A co-ordinated effort in 14 countries. J. Atmos. Chem. 49:3-13. doi:10.1007/s10874-004-1210-2

Tarricone, K., G. Wagner, and R. Klein. 2015. Toward standardization of sample collection and preservation for the quality of results in biomonitoring with trees: A critical review. Ecol. Indic. 57:341-359. doi:10.1016/j. ecolind.2015.05.012

WHO. 2005. Nickel in drinking-water. Background document for development of WHO guidelines for drinking-water quality. WHO/SDE/ WSH/05.08/55. World Health Org., Geneva, Switzerland.

Yadav, R.K., P.S. Minhas, K. Lal, R.K. Chaturvedi, G. Yadav, and T.P. Verma. 2015. Accumulation of metals in soils, groundwater and edible parts of crops grown under long-term irrigation with sewage mixed industrial effluents. Bull. Environ. Contam. Toxicol. 95:200-206. doi:10.1007/ s00128-015-1547-z 